\title{
The mediation role of financial literation in ensuring MSMEs sustainability: An organizational characteristics perspective
}

Arik Prasetya ${ }^{1}$, Kusdi Rahardjo ${ }^{2}$, Mukhammad Kholid Mawardi ${ }^{3}$, Raden Rustam Hidayat $^{4}$, Yudha Prakasa ${ }^{5^{*}}$

${ }^{1}$ Department of Business Administration, Faculty of Administrative Science, Universitas Brawijaya, Malang, Indonesia

${ }^{2}$ Department of Business Administration, Faculty of Administrative Science, Universitas Brawijaya, Malang, Indonesia

${ }^{3}$ Department of Business Administration, Faculty of Administrative Science, Universitas Brawijaya, Malang, Indonesia

${ }^{4}$ Department of Business Administration, Faculty of Administrative Science, Universitas Brawijaya, Malang, Indonesia

${ }^{5}$ Department of Business Administration, Faculty of Administrative Science, Universitas Brawijaya, Malang, Indonesia

*Corresponding Author(s) Email: y.prakasa87@ub.ac.id

\section{ABSTRACT}

The Micro, Small, and Medium Enterprise (MSMEs) sector has been recognized as an essential contributor to the economic development of Indonesia. However, the sustainability of MSMEs in Indonesia is still relatively low compared to the rest of ASEAN countries with similar levels of economic growth. This study aims to extend previous studies on the relationship between MSMEs characteristics and their sustainability by specifically including financial literation as a mediation role. This study used proportional random sampling as a sampling technique. A total of 191 MSMEs ownermanagers questionnaire data were processed by using Partial Least Square analysis. This study confirmed the positive influence of MSMEs characteristics on financial literacy and financial literacy on the sustainability of MSMEs. Moreover, financial literation proves to be a significant mediator of MSMEs sustainability. This study suggests that MSMEs owner-managers need to be financially literate as it can enable them to make a good financial decision that can ensure their business sustainability.

Keywords: MSME; Sustainability; Financial Literacy; Organization Characteristics; Entrepreneurs
JEL Code:

D23, G53, L26, M14

DOI:

10.31106/jema.v18i1.10356

Article History:

Received 2021-02-07

Reviewed 2021-02-25

Revised 2021-03-14

Accepted 2021-03-29

Licensed:

CC-BY 
The mediation role of financial literation in ensuring MSMEs sustainability: An organizational characteristics perspective by Arik Prasetya, Kusdi Rahardjo, Mukhammad Kholid Mawardi,

Raden Rustam Hidayat, Yudha Prakasa

\section{Introduction}

The role of MSMEs in the economic growth of a country is widely known and utilized to improve the national economy in many countries including Indonesia. Currently, the data shows that SMEs in Indonesia grows significantly up to $97.2 \%$ and contribute to GDP for $57.8 \%$ (Wignaraja, 2015), while Small Business contributes up to $45 \%$ of total employment and 33\% of national income in developing countries (Kumar, 2017). The contribution of SMEs is also supported by the growth of production in small and micro industries from 2017 to 2019 with an annual percentage of $4.74 \%, 5.66 \%$, and 5.80\% (Kumar, 2017). However, the competitiveness of SMEs in Indonesia is relatively low compared to other ASEAN countries such as Singapore, Malaysia, and Thailand. Bongomin et al. (2017) added that the lack of access to formal and non-formal financial services is one of the biggest obstacles for SMEs to be competitive and grow. Along with that, other issues such as human resource capacity and capability, ownership, marketing, technology adoption, and other problems related to business management also become the reason why Indonesia's SMEs are difficult to compete (Abor \& Quartey, 2010) and maintain their business sustainability in the future.

As many MSMEs are a force to reconfigure their business process to remain to sustain in a complex and competitive world, the terms of sustainability have become a common topic to discuss in measuring business performances. Although, it has been a controversial topic since it has multiple interpretations, Salimath \& Jones (2011) generalized the measurement and interpretation of this concept that is dependent on the aims and interests of the researchers. Yusoff et al. (2019) argued that the sustainability of the business is accomplished when an organization can enable the balance of economic and social aspects while keeping environmental sustainability. Fitria \& Rahman (2018) added that "the sustainability of MSMEs is also seen by the ability of its return on investment, complaints from consumers, income sustainability and the increasing number of customers. It shows how a business can survive and continue to develop during the ongoing business competition." Therefore, the ability to manage finances and expand financial access is highly demanded to achieve the desired goal of MSMEs sustainability.

Financial literacy has been identified as an important source of knowledge for financial decision making (Ye \& Kulathunga, 2019) which can guide business stakeholders to make financial decisions and use financial product options (Bongomin et al., 2017). Financial literacy can also ensure the financial sustainability of individuals, families, companies, and 
the national economy (Swiecka et al., 2020). Meanwhile, Lusardi \& Tufano (2015) stated that financial literacy helps business stakeholders gain adequate financial knowledge, skills, and capabilities in preparing a business financial strategy. As a consequence, business stakeholders should be more effective and efficient in planning, implementing, and supervising the implementation of their business finances. Several previous studies by Widayanti et al. (2017), Hapsoro \& Iswara (2019), Ye \& Kulathunga (2019) shows that the role of financial literacy also influences business sustainability. Furthermore, the crucial role of the organization as a business driver should also be considered especially in terms of its capability to manage the business and implement its knowledge and skills properly. Successful organizations realize that their attention must be directed to the knowledge management process in which consists of the creation, conversion, dissemination, and contribution of knowledge, as well as the methods of storing, selecting, processing, using, and assessing knowledge to excel their performance (Abualoush et al., 2018). Concerning originality, this study is immensely scattered compared to other studies because it examines the indirect relationship of organizational characteristics to MSMEs sustainability where financial literacy is used as a mediating variable. Furthermore, it uses the object of the leading MSMEs sector which consists of 5 types of business sectors. It also uses objects across the MSME sector so that this study expands the generalization of the previous study's findings.

\section{Literature Review}

\section{Sustainability in The MSMEs Sector}

Sustainability is a controversial issue because it means different things to a different study. There is no standard definition of sustainability, especially in the corporate context. Therefore, the measurement and interpretation of these constructs depend on the aims and interests of the researchers. Salimath \& Jones (2011) said that "there is no consensus on a unified definition of sustainability. Furthermore, the measurement and interpretation of this construct appear to be idiosyncratic to specific aims or research interest." In a simple word, sustainability is no more than a static word, the ability to continue unchanged. The concept of sustainability is also often linked with the sustainable development framework. Aras \& Crowther (2008) stated that the terms of sustainability and sustainable development in various points of view are synonymous. DeJoy et al. (2010) added that

"[...] while corporate sustainability recognizes that company growth and profitability is important, it also requires companies to pursue community goals, particularly those 
The mediation role of financial literation in ensuring MSMEs sustainability: An organizational characteristics perspective by Arik Prasetya, Kusdi Rahardjo, Mukhammad Kholid Mawardi,

Raden Rustam Hidayat, Yudha Prakasa

related to sustainable development - environmental protection, economic development, social justice, and equality."

The literature on sustainability emphasizes the need for systematic thinking to conserve natural resources, eliminate poverty, promote equality, reduce population growth and improve quality of life (Velazquez et al., 2011). Aras \& Crowther (2008) categorized four dimensions of sustainability that are needed to be recognized and analyzed, namely social influence (which is defined as a measure of the impact of the community on the company in terms of social contracts and stakeholder influence), environmental impact (which is defined as a measure of the impact of company actions on the geophysical environment), organizational culture (the interaction and relationship between the company and its internal stakeholders), and financial (which is measures an adequate return on the level of risk taken). On the other hand, Yusoff et al. (2019) and Asif et al. (2011) stated that sustainability also can be interpreted as adopting a business strategy and activities that meet the needs of the company and stakeholders while protecting, maintaining, and enhancing human and natural resources needed in the future. However, the quantitative measurement of corporate sustainability remains debatable. The objectives of measuring sustainability also vary depending on researchers' interests. One of the most frequently used approaches in measuring corporate sustainability is the triple bottom line approach. Faupel \& Schwach (2011) stated that "the objective of a sustainability measurement is assessing the contribution of an entity (eg, company) to sustainability comprising all three dimensions: environmental, social, and economic." While environment sustainability measurement focus in measures the impact of business process on natural resources (such as air, water, and waste emissions), social and economic sustainability measurement focus in measures the implementation of corporate governance, motivation, incentives, safety, health, human resource development, human rights, ethical behavior, and the maintenance or improvement of a company's success such as technology, innovation, knowledge management, purchasing, and sustainability.

Several previous studies from Eniola \& Entebang (2017), Klewitz (2017), Ye \& Kulathunga (2019) indicate that the term of firm sustainability has a similar meaning with SMEs sustainability in general. Ye \& Kulathunga (2019) explained the eight metrics of SMEs sustainability that consist of a reduction in operating costs, an increase in the rate of profit growth and market share, customer satisfaction, speed of customer order confirmation, speed of response to market demand, reduction of product or service delivery cycle times, profit as a percentage of sales and returns on investment (ROI). In addition, Schwab et al. (2019), 
Amusawi et al. (2019) evaluate business sustainability by using a financial approach such as the comparison between income earned and operating expense, credit limit level, and the liquidity level of the company. The financial attitude and behavior of MSMEs ownermanager play a critical role to ensure their business sustainability. Rai et al. (2019) strengthened that financial attitude and behavior have a strong association with financial literacy, especially in working women. Unfortunately, studies from Dai et al. (2021) and Kostini \& Raharja (2020) related to this topic find the opposites. Many of Indonesia's MSMEs owner-manager has not proper financial planning for the future due to their lack of financial literacy. Many of them do not have a standardized financial statement and prefer to use individual funding as their main business capital.

\section{Organizational Characteristics}

Organizational characteristics are characteristics of the management model adopted by the organization through its structure or strategy (Magnier-Watanabe \& Senoo, 2008). Gold et al. (2001) stated that there are three main infrastructures capabilities in the organization that can maximize their social impact which consists of technology, structural, and cultural. While technology infrastructure capabilities represent the technology-related sources that can enhance the organization's operational capability and strength the level of competitiveness of the organization (Liu et al., 2016; Irfan et al., 2019), structural and cultural infrastructure capabilities are defined by Gold et al. (2001), Adobor et al. (2019), Mesfin et al. (2020), and Baskaran (2018) as an organizational hierarchy that used as the formal allocation of activities and resources among people" and a set of values, belief, norms and trust mechanism that distinguishes one organization from another. Structural and cultural infrastructures are identified as important elements in determining successful knowledge management initiatives (Urinov, 2020; Santoro \& Gopalakrishnan, 2000; Intezari et al., 2017). Moreover, Allen et al. (2017) stated that culture, climate, leadership, power, participation, and communication are other characteristics that can differ in any type of organization. For example, most MSMEs have a flat hierarchy with centralized authority (which is the business owner who is also the manager), fast results-oriented, flexible, unified, and fluid culture due to their simple organizational structure (Siegel et al., 2019).

Concerning organizational resources, the knowledge possessed by individuals who are part of the organization becoming crucial as it cannot be shared efficiently without having adequate competence, relevant to realizing the competencies needed to share knowledge (Gaál et al., 2013). Furthermore, Adomako et al. (2016) classified "financial literacy as a part 
The mediation role of financial literation in ensuring MSMEs sustainability: An organizational characteristics perspective by Arik Prasetya, Kusdi Rahardjo, Mukhammad Kholid Mawardi,

Raden Rustam Hidayat, Yudha Prakasa

of internal firm capability that can complement access to finance to achieve superior growth outcomes." Organizations that are rapidly using new technologies to create collaborative work and knowledge-sharing culture can uplift their organizational performance in an efficient way (Kulathunga et al., 2020). Besides, Brown et al. (2017) added that cultural differences prove to be significant financial literacy predictors between students with different languages and socio-economic backgrounds. Therefore, the proposed hypotheses can be described as follows.

$\mathrm{H}_{1}$ : There is a positive relationship between MSMEs characteristics and financial literacy.

\section{Financial Literacy}

Financial literacy has become a critical determinant in organizational decision-making and strategic objectives for long-term financial planning (Allgood \& Walstad, 2013; Lusardi \& Mitchell, 2014). Financial literacy can be interpreted as the ability of an individual to maximize their potential knowledge and skills to make appropriate financial decisions. It includes the ability to discern financial choices (savings, investments, debt, insurance, asset accumulation, loans, and pension) and to use basic financial knowledge combining with comprehensive skill sets, communication, and networks to achieve desirable objectives (Margaretha \& Pambudhi, 2015; Lusardi \& Mitchell, 2014). Stadler et al. (2013) found that financially literate managers could produce better financial strategic (investment) decisions and know how to respond to any dynamic case competently and rapidly. Moreover, Eniola \& Entebang (2017) added that there is a positive influence of MSMEs owner-manager financial knowledge, financial awareness, and financial attitudes in changing financial literacy on the improvement of company performance.

Several previous studies from Ambarwati \& Zuraida (2020), Ye \& Kulathunga (2019), Hapsoro \& Iswara (2019) found that there were positive associations of financial literacy to MSMEs sustainability. The more financially literate MSMEs owners and managers, the higher the possibility of sustainability MSMEs will be. Furthermore, a study from Makhloufi et al. (2018) also found that to creating a knowledge-sharing culture, MSMEs sustainability can also be influenced by organizational characteristics. The implementation of a knowledgesharing culture will encourage companies to be more competitive and have good business continuity. Besides, financial literacy is the perception of how to obtain financial knowledge and apply financial knowledge that is owned in running a business. Companies acquire and apply knowledge influenced by the organizational structure that supports the search and 
creation of knowledge (Robbins, 2003). Furthermore, organizational culture characteristics also play a role in creating a knowledge exchange climate (Cameron et al., 2014). Knowledge sharing culture will encourage companies to be competitive and have good business continuity. For SMEs, knowledge about financial literacy is proven to improve business sustainability (Ye \& Kulathunga, 2019). While the antecedent factor of increasing organizational knowledge, including financial literacy, is the organizational characteristics of SMEs regarding structure, culture, and technology (Robbins, 2003; Cameron et al., 2014; Hatch, 1993). The mediation role of financial literacy on the sustainability of MSME businesses is proven to be influential as illustrated by the research of Bongomin et al. (2017). Although it does not explicitly describe business sustainability, it refers to business growth which is also a measure of the sustainability of MSME businesses Yanti et al. (2018). This is relevant to Robbin's (2003) argument that stated organizational knowledge including financial literacy, can improve organizational performance and sustainability if it is strengthened by good organizational characteristics.

$\mathrm{H}_{2}$ : There is a positive relationship between financial literacy and MSMEs sustainability.

$\mathrm{H}_{3}$ : There is a positive relationship between MSMEs characteristics and MSMEs sustainability with financial literacy play a mediator role.

\section{Methods}

This study can be classified as exploratory research with a quantitative approach. The data used is primary data which is collected directly through the distribution of a survey questionnaire with five-point of Likert as a measurement scale. The questionnaire contains the perceptions of MSMEs owners-managers on organizational characteristics, financial literacy, and business sustainability. In this study, organizational characteristics measurements were adapted from that has Robbins (2003) and Cameron et al. (2014) indicators including technical, structural, and cultural assessment instruments. While financial literacy is measured by the scale developed by Oseifuah et al. (2018) and Hussain et al. (2018), MSMEs sustainability measurement was derived from Bourlakis et al. (2014).

Figure 1. Research Framework

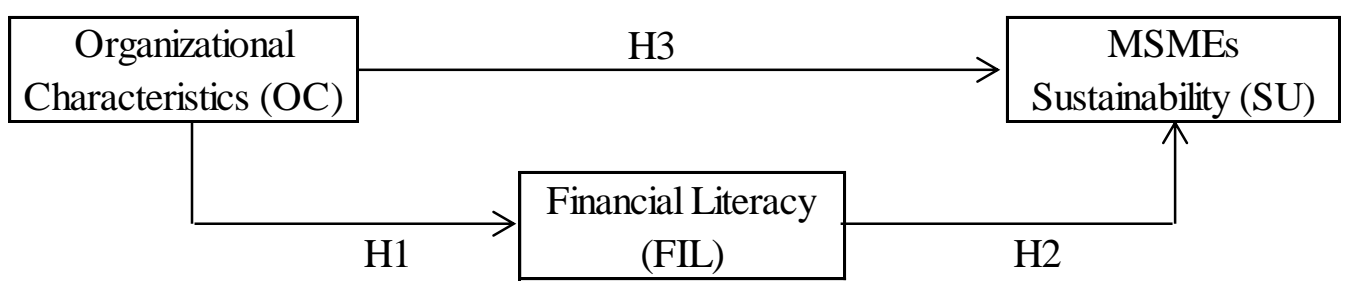


The mediation role of financial literation in ensuring MSMEs sustainability: An organizational characteristics perspective by Arik Prasetya, Kusdi Rahardjo, Mukhammad Kholid Mawardi,

Raden Rustam Hidayat, Yudha Prakasa

Table 1. Research Instruments

\begin{tabular}{|c|c|c|}
\hline Variables & Code & Item \\
\hline \multirow{9}{*}{$\begin{array}{l}\text { Organizational } \\
\text { Characteristics } \\
\text { (OC) }\end{array}$} & OC1 & Organizational structure can support knowledge creation. \\
\hline & OC2 & $\begin{array}{l}\text { The organizational structure encourages employees to do knowledge } \\
\text { sharing }\end{array}$ \\
\hline & OC3 & Having preferences regarding knowledge to create competitiveness \\
\hline & OC4 & $\begin{array}{l}\text { Having preferences regarding value knowledge exchange within } \\
\text { organizations }\end{array}$ \\
\hline & OC5 & $\begin{array}{l}\text { Having preferences regarding value knowledge exchange between } \\
\text { organizations }\end{array}$ \\
\hline & OC6 & Having preferences in providing knowledge-based solutions \\
\hline & OC7 & Technology in organizations supports interactions between members \\
\hline & OC8 & Technology in the organization supports the creation of new knowledge \\
\hline & OC9 & $\begin{array}{l}\text { Technology in organizations supports collaboration/cooperation in } \\
\text { running a business }\end{array}$ \\
\hline \multirow{8}{*}{$\begin{array}{l}\text { Financial } \\
\text { Literacy (FIL) }\end{array}$} & FIL1 & Having financial knowledge from government agencies training \\
\hline & FIL2 & Having financial knowledge from private agencies training \\
\hline & FIL3 & $\begin{array}{l}\text { Participate in financial management training organized by government } \\
\text { agencies }\end{array}$ \\
\hline & FIL4 & $\begin{array}{l}\text { Participate in financial management training organized by other than } \\
\text { government agencies }\end{array}$ \\
\hline & FIL5 & There is a separation of business finance and personal finance \\
\hline & FIL6 & $\begin{array}{l}\text { There is a separation of duties between the financial registrar and the } \\
\text { business finance holder }\end{array}$ \\
\hline & FIL7 & There is a record of cash receipts and cash disbursements \\
\hline & FIL8 & There are financial reports of my business \\
\hline \multirow{11}{*}{$\begin{array}{l}\text { MSMEs } \\
\text { Sustainability } \\
\text { (SU) }\end{array}$} & SU1 & I'm able to manage finances appropriately and adequately \\
\hline & SU2 & I'm able to divide and use finances under the budget item \\
\hline & SU3 & I'm able to receive orders from consumers in large quantities \\
\hline & SU4 & I'm able to receive customized/specialized orders \\
\hline & SU5 & I'm able to design and develop new products using the latest technology \\
\hline & SU6 & I'm able to distribute products in fast time \\
\hline & SU7 & I'm having the definitive program to improve employee competence \\
\hline & SU8 & $\begin{array}{l}\text { I'm having the definitive policies in maintaining and improving the } \\
\text { quality of products/services }\end{array}$ \\
\hline & SU9 & I'm having good relationships with suppliers and consumers \\
\hline & SU10 & I always pay attention to employee welfare \\
\hline & SU11 & I always comply with applicable government regulations \\
\hline
\end{tabular}


Table 2. Reliability, Convergent Validity, and Average Variance Extracted (AVE)

\begin{tabular}{|c|c|c|c|c|}
\hline $\begin{array}{l}\text { Construct/ } \\
\text { Items }\end{array}$ & $\begin{array}{c}\text { Cronbach's } \\
\text { Alpha }\end{array}$ & AVE & $\begin{array}{l}\text { Composite } \\
\text { Reliability }\end{array}$ & $\begin{array}{l}\text { Loading } \\
\text { Factor }\end{array}$ \\
\hline OC & 0.891 & 0.535 & 0.912 & \\
\hline OC1 & & & & 0.955 \\
\hline $\mathrm{OC} 2$ & & & & 0.955 \\
\hline OC3 & & & & 0.845 \\
\hline OC4 & & & & 0.871 \\
\hline OC5 & & & & 0.872 \\
\hline OC6 & & & & 0.834 \\
\hline OC7 & & & & 0.942 \\
\hline OC8 & & & & 0.917 \\
\hline OC9 & & & & 0.935 \\
\hline FIL & 0.873 & 0.532 & 0.900 & \\
\hline FIL1 & & & & 0.769 \\
\hline FIL2 & & & & 0.779 \\
\hline FIL3 & & & & 0.862 \\
\hline FIL4 & & & & 0.872 \\
\hline FIL5 & & & & 0.899 \\
\hline FIL6 & & & & 0.843 \\
\hline FIL7 & & & & 0.920 \\
\hline FIL8 & & & & 0.922 \\
\hline SU & 0.857 & 0.520 & 0.886 & \\
\hline SU1 & & & & 0.939 \\
\hline SU2 & & & & 0.927 \\
\hline SU3 & & & & 0.701 \\
\hline SU4 & & & & 0.871 \\
\hline SU5 & & & & 0.830 \\
\hline SU6 & & & & 0.810 \\
\hline SU7 & & & & 0.668 \\
\hline SU8 & & & & 0.871 \\
\hline SU9 & & & & 0.872 \\
\hline SU10 & & & & 0.819 \\
\hline SU11 & & & & 0.748 \\
\hline
\end{tabular}


The mediation role of financial literation in ensuring MSMEs sustainability: An organizational characteristics perspective by Arik Prasetya, Kusdi Rahardjo, Mukhammad Kholid Mawardi,

Raden Rustam Hidayat, Yudha Prakasa

Table 3. Discriminant Validity

\begin{tabular}{llll}
\hline Constructs & OC & FIL & SU \\
\hline Organizational Characteristics (OC) & 0.732 & & \\
Financial Literacy (FIL) & 0.261 & 0.730 & \\
MSMEs Sustainability (SU) & 0.486 & 0.547 & 0.648 \\
\hline
\end{tabular}

The sampling method applied in this study is the sector-based proportional random sampling technique. Proportional random sampling is one of the sampling technique that used "when members or elements that are not homogeneous and stratified proportionately". The five leading sectors use in this study are food and beverage, fashion, application, animated design, and craft in Malang, Indonesia. Malang was chosen as the object of study due to the reason that this city was established as one of the 10 creative cities in Indonesia and the fact of huge economic contribution of MSMEs (Khouroh et al., 2020). Moreover, the criterion of MSMEs used as the initial selection of respondents is MSMEs that have employees of 99 with the maximum total asset of IDR 10 Billion. A total sample of 191 MSMEs ownersmanagers was obtained and used to examine the associations between organizational characteristics, financial literacy, and business sustainability by using Partial Least Square (PLS). PLS is a variant based on structural equation analysis that can evaluate both measurement and structural models at the same time (Mardijuwono \& Subianto, 2018). PLS analysis has two main results which are the inner and outer model. While the inner model refers to the connection of the latent variables in a structural model or path matrix format Ajibola et al. (2018), the outer model is represented by the value of construct validity and reliability. Hair Jr et al. (2016) added that models can be classified as valid and reliable when the value of an outer factor is 0.500 , the value of composite reliability and AVE value of each construct that is greater than 0.700 and 0.500 , the result of Cronbachs' alpha test that exceeds 0.700 , and the result of discriminant validity of each construct that is greater than the correlation value of the construct with the other constructs within a model. The results of the validity and reliability testing can be seen in Tables 2 and 3 .

\section{Result and Discussion}

The description of the majority of respondents in Table 4 shows that $61 \%$ of the respondents are male with junior high school backgrounds. Above 50\% of respondents in this study are classified as experienced businessmen/women with the majority of them choose 
culinary as their business focus. Unfortunately, there are 55\% of respondents have not been registered and have not a legal entity. This nature of condition limited their access to government facilities related to increasing financial literacy and inclusion.

Table 5 shows that all the proposed hypotheses in this study are supported as the p-value of each proposed hypothesis was lower than $0.050(0.000,0.000,0.001)$. This study confirmed the positive influence of MSMEs characteristics on financial literacy and financial literacy on the sustainability of MSMEs. It means that the bigger technology investment and the more flexible the structure of MSMEs in accommodating knowledge-sharing culture, the higher the financial literacy will be. This study supports the conclusion of previous studies by Zaridis \& Mousiolis (2014) and Eniola \& Entebang (2017). The result of this study also supports Drexler et al. (2014), Widayanti et al. (2017), and Swiecka et al. (2020) conclusion that stated that the more financially literate of MSMEs owner-managers, the higher the probability of MSMEs to sustain. Although it does not directly affect the sustainability of MSME businesses, both financial literacy and the sustainability of SMEs are two things that need to go hand in hand to improve MSMEs' performance.

Table 4. Demographic Profile

\begin{tabular}{lclc}
\hline Demographic Profile & Percentage & Demographic Profile & Percentage \\
\hline Gender : & & Duration of Business : & \\
Male & $61 \%$ & $1-7$ & $7 \%$ \\
Female & $39 \%$ & $8-15$ & $41 \%$ \\
Educational Level : & & $16-23$ & $31 \%$ \\
Elementary School & $8 \%$ & $24-31$ & $13 \%$ \\
Junior High School & $49 \%$ & $32-39$ & $3 \%$ \\
Senior High School & $19 \%$ & $40-47$ & $2 \%$ \\
Diploma & $5 \%$ & $48-56$ & $2 \%$ \\
Bachelor & $18 \%$ & $\geq 57$ & $1 \%$ \\
Master & $1 \%$ & Business Status : & \\
Business Sector : & & Non-Registered & $55 \%$ \\
Culinary & $67 \%$ & Company Registration Certificate & $10 \%$ \\
Craft & $17 \%$ & Limited Partnership & $7 \%$ \\
Fashion & $9 \%$ & Private Company & $27 \%$ \\
Technology & $4 \%$ & & \\
Art - Photography - Design & $3 \%$ & & \\
\hline
\end{tabular}


The mediation role of financial literation in ensuring MSMEs sustainability: An organizational characteristics perspective by Arik Prasetya, Kusdi Rahardjo, Mukhammad Kholid Mawardi,

Raden Rustam Hidayat, Yudha Prakasa

Table 5. Hypotheses Testing

\begin{tabular}{lccccc}
\hline Hypotheses & Estimates & SE & t & P & Decision \\
\hline $\mathrm{H}_{1}$ OC -> FIL & 0.261 & 0.065 & 4.010 & 0.000 & Supported \\
$\mathrm{H}_{2}$ FIL -> SU & 0.547 & 0.061 & 8.974 & 0.000 & Supported \\
$\mathrm{H}_{3}$ OC -> FIL -> SU & 0.143 & 0.041 & 3.263 & 0.001 & Supported \\
\hline
\end{tabular}

Margaretha \& Pambudhi (2015), Lusardi \& Mitchell (2014), and Stadler et al. (2013) added that financially literate managers could produce better financial strategic (investment) decision and know how to respond to any dynamic case competently and rapidly. Moreover, Eniola \& Entebang (2017) added that there is a positive influence of MSMEs owner-manager financial knowledge, financial awareness, and financial attitudes in changing financial literacy on the improvement of company performance and sustainability. Moreover, the nature of the majority of respondents in this study that can be classified as Millennials (Y generation) indicates that they are adaptive, confident, high self-esteem, assertiveness, achievement-focused, and tech-savvy (Miswanto et al., 2020) affects flexibility, fluidity, and efficiency of organizational characteristics.

Several cases were found by Bhushan (2013) and Krishna et al. (2010) related to the MSMEs owner-manager who are having lack basic financial knowledge, they will experience difficulties in financial management, use of credit, and financial plans so that it will affect their business continuity, financial consumption practices, and business flexibility. The leading sectors of MSMEs in Malang, Indonesia have realized that their financial knowledge has assisted them to implement financial management practices to maintain efficiency, help their business to be flexible in their production capacity. This action reflects that MSMEs owner-manager has sufficient financial literacy to access financial services to maintain the sustainability of their businesses.

Moreover, financial literation proves to be a significant mediator of MSMEs sustainability in this study. This result is supporting the study conducted by Makhloufi et al. (2018) which states that the infrastructure owned by MSMEs to improve sustainability is reflected in the presence of supporting technology. The ownership of an adequate technology will benefit the organization in enhancing transaction speed, close communication, effective information, and ease of updating transactions and business re-engineering. The technological context in this study is one of the characteristics of the leading sector of MSMEs in Malang in conducting production, marketing, and distribution activities. This study also strengthens 
the suggestion that MSMEs owner-managers need to be financially literate as it can enable them to make good financial decisions and access external financial support that can ensure their business sustainability especially in light of the recent dynamic situations.

\section{Conclusion and Suggestion}

The result of this study reveals that there are positive associations of MSMEs characteristics on financial literacy and financial literacy on the sustainability of MSMEs. Financial literation proves to be a significant mediator of MSMEs sustainability in this study. These results reflect that improving MSMEs sustainability and financial literacy requires sufficient organizational characteristics and infrastructure. Once they get financially literate, it could enable them to produces better financial strategic (investment) decisions and know how to respond to any dynamic case in competent and rapid manner. Thus, it will affect their business performances and sustainability. Several limitations in this study are this study is a short-time explanatory study, therefore, the results of this study do not describe an object in the long term. Future researchers should conduct in a longer period to deepen this study results. The object of this study that only focuses on MSMEs that are established in Malang, Indonesia is cannot be generalized to other cities in Indonesia. Future studies should choose a wider location to expand the generalization of the results. Finally, the result of this study that proved the significant mediation role of financial literacy needed to expand into the various context of the study.

\section{References}

Abor, J., \& Quartey, P. (2010). Issues in SME development in Ghana and South Africa. International Research Journal of Finance and Economics, 39(6), 215-228.

Abualoush, S., Masa'deh, R., Bataineh, K., \& Alrowwad, A. (2018). The Role of Knowledge Management Process and Intellectual Capital as Intermediary Variables between Knowledge Management Infrastructure and Organization Performance. Interdisciplinary Journal of Information, Knowledge, and Management, 13, 279-309. https://doi.org/10.28945/4088

Adobor, H., Kudonoo, E., \& Daneshfar, A. (2019). Knowledge management capability and organizational memory: a study of public sector agencies. International Journal of Public Sector Management, 32(6), 671-687. https://doi.org/10.1108/IJPSM-10-20180225

Adomako, S., Danso, A., \& Ofori Damoah, J. (2016). The moderating influence of financial 
The mediation role of financial literation in ensuring MSMEs sustainability: An organizational characteristics perspective by Arik Prasetya, Kusdi Rahardjo, Mukhammad Kholid Mawardi,

Raden Rustam Hidayat, Yudha Prakasa

literacy on the relationship between access to finance and firm growth in Ghana. Venture Capital, 18(1), 43-61. https://doi.org/10.1080/13691066.2015.1079952

Ajibola, L.-S. A., Shohaimi, S., Adam, M. B., Nadzir, M. N. H. M., \& Segun, O. E. (2018). Partial Least Square Path analysis of knowledge, attitude and practice regarding dengue. Journal of Biostatistics and Epidemiology, 4(4), 222-231.

Allen, J. D., Towne, S. D., Maxwell, A. E., DiMartino, L., Leyva, B., Bowen, D. J., Linnan,

L., \& Weiner, B. J. (2017). Measures of organizational characteristics associated with adoption and/or implementation of innovations: A systematic review. BMC Health Services Research, 17(1), 1-10. https://doi.org/10.1186/s12913-017-2459-x

Allgood, S., \& Walstad, W. (2013). Financial literacy and credit card behaviors: A crosssectional analysis by age. Numeracy, 6(2), 1-26. http://dx.doi.org/10.5038/19364660.6.2.3

Ambarwati, L., \& Zuraida, L. (2020). Pengaruh financial literacy terhadap business sustainability pada UMKM Desa Panggungharjo. Kajian Bisnis Sekolah Tinggi Ilmu Ekonomi Widya Wiwaha, 28(1), 1-12. https://doi.org/10.32477/jkb.v28i1.27

Amusawi, E. G., Almagtome, A. H., \& Shaker, A. S. (2019). Impact of Lean Accounting Information on The Financial performance of the Healthcare Institutions: A Case study. Journal of Engineering and Applied Sciences, 14(2), 399-589.

Aras, G., \& Crowther, D. (2008). Governance and sustainability. Management Decision, 46(3), 433-448. https://doi.org/10.1108/00251740810863870

Asif, M., Searcy, C., Zutshi, A., \& Ahmad, N. (2011). An integrated management systems approach to corporate sustainability. European Business Review, 23(4), 353-367. https://doi.org/10.1016/j.jclepro.2011.10.034

Baskaran, S. (2018). Mediation effect of knowledge management enablers on the relationship between organizational characteristics and entrepreneurial orientation. Gadjah Mada International Journal of Business, 20(1), 1-32. https://doi.org/10.22146/gamaijb.23323

Bhushan, P. et al. (2013). Financial Literacy and Its Determinant. International Journal of Engineering, Business and Enterprise Applications (IJEBEA), 13-145(2279-0039), 155-160. http://iasir.net/IJEBEApapers/IJEBEA13-145.pdf

Bongomin, G. O. C., Ntayi, J. M., Munene, J. C., \& Malinga, C. A. (2017). The relationship between access to finance and growth of SMEs in developing economies: Financial literacy as a moderator. Review of International Business and Strategy, 27(4), 520-538. https://doi.org/10.1108/RIBS-04-2017-0037 
Bourlakis, M., Maglaras, G., Aktas, E., Gallear, D., \& Fotopoulos, C. (2014). Firm size and sustainable performance in food supply chains: Insights from Greek SMEs. International Journal of Production Economics, 152, 112-130. https://doi.org/10.1016/j.ijpe.2013.12.029

Brown, M., Henchoz, C., \& Spycher, T. (2017). Culture and financial literacy. Journal of Economic Behavior and Organization, Forthcoming. https://dx.doi.org/10.2139/ssrn.2916636

Cameron, Kim S, Quinn, R. E., DeGraff, J., \& Thakor, A. V. (2014). Competing values leadership. Edward Elgar Publishing.

Dai, R. M., Kostini, N., \& Tresna, P. W. (2021). The influence of financial attitude and financial literacy on behavioral finance: A study on leading small and medium enterprises in Cimahi City, Indonesia. Review of Integrative Business and Economics Research, 10, 322-329.

DeJoy, D. M., Wilson, M. G., Vandenberg, R. J., McGrath-Higgins, A. L., \& Griffin-Blake, C. S. (2010). Assessing the impact of healthy work organization intervention. Journal of Occupational and Organizational Psychology, 83(1), 139-165. https://doi.org/10.1348/096317908X398773

Drexler, A., Fischer, G., \& Schoar, A. (2014). Keeping it simple: Financial literacy and rules of thumb. American Economic Journal: Applied Economics, 6(2), 1-31. https://doi.org/10.1257/app.6.2.1

Eniola, A. A., \& Entebang, H. (2017). SME managers and financial literacy. Global Business Review, 18(3), 559-576. https://doi.org/10.1177\%2F0972150917692063

Faupel, C., \& Schwach, S. (2011). Measuring corporate sustainability, maximizing shareholder value. Ernst \&Young.

Fitria, M., \& Rahman, A. (2018). The effect of financial literacy on growth and sustainability of smes (small and medium enterprises) in the handicraft sector in Padang City. International Journal of Progressive Sciences and Technologies, 10(2), 382-393. http://dx.doi.org/10.52155/ijpsat.v10.2.610

Gaál, Z., Szabó, L., \& Csepregi, A. (2013). Organizational Characteristics and Social Competences: Are there differences within social competences connected with communication and co-operational skills based on the characteristics of organizations? The International Journal of Management Science and Information Technology (IJMSIT), 10-(Dec), 176-193.

Gold, A. H., Malhotra, A., \& Segars, A. H. (2001). Knowledge management: an 
The mediation role of financial literation in ensuring MSMEs sustainability: An organizational characteristics perspective by Arik Prasetya, Kusdi Rahardjo, Mukhammad Kholid Mawardi,

Raden Rustam Hidayat, Yudha Prakasa

organizational capabilities perspective. Journal of Management Information Systems, 18(1). https://doi.org/10.1080/07421222.2001.11045669

Hair Jr, J. F., Hult, G. T. M., Ringle, C., \& Sarstedt, M. (2016). A primer on partial least squares structural equation modeling (PLS-SEM). Sage publications.

Hapsoro, D., \& Iswara, A. S. (2019). Does Financial Literation Moderate The Effect of Funding on The Sustainability of Micro Enterprises. The Indonesian Journal of Accounting Research, 22(3). http://doi.org/10.33312/ijar.448

Hatch, M. J. (1993). The dynamics of organizational culture. Academy of Management Review, 18(4), 657-693. https://doi.org/10.5465/amr.1993.9402210154

Hussain, J., Salia, S., \& Karim, A. (2018). Is knowledge that powerful? Financial literacy and access to finance: An analysis of enterprises in the UK. Journal of Small Business and Enterprise Development, 25(6), 985-1003. https://doi.org/10.1108/JSBED-01-20180021

Intezari, A., Taskin, N., \& Pauleen, D. J. (2017). Looking beyond knowledge sharing: an integrative approach to knowledge management culture. Journal of Knowledge Management, 21(2), 492-515. https://doi.org/10.1108/JKM-06-2016-0216

Irfan, M., Wang, M., \& Akhtar, N. (2019). Impact of IT capabilities on supply chain capabilities and organizational agility: a dynamic capability view. Operations Management Research, 12(3), 113-128. https://doi.org/10.1007/s12063-019-00142-y

Khouroh, U., Sudiro, A., Rahayu, M., \& Indrawati, N. (2020). The mediating effect of entrepreneurial marketing in the relationship between environmental turbulence and dynamic capability with sustainable competitive advantage: An empirical study in Indonesian MSMEs. Management Science Letters, 10(3), 709-720.

Klewitz, J. (2017). Grazing, exploring and networking for sustainability-oriented innovations in learning-action networks: an SME perspective. Innovation: The European Journal of Social Science Research, 30(4), 476-503. https://doi.org/10.1080/13511610.2015.1070090

Kostini, N., \& Raharja, S. J. (2020). Analysis of Financial Behavior of SMes in the Creative industries in Bandung City, Indonesia. Review of Integrative Business and Economics Research, 9(1), 131-139.

Krishna, A., Rofaida, R., \& Sari, M. (2010). Analisis tingkat literasi keuangan di kalangan mahasiswa dan faktor-faktor yang mempengaruhinya (Survey pada Mahasiswa Universitas Pendidikan Indonesia). Proceedings of The 4th International Conference on 
Teacher Education, 4(1), 552-560.

Kulathunga, K., Ye, J., Sharma, S., \& Weerathunga, P. R. (2020). How Does Technological and Financial Literacy Influence SME Performance: Mediating Role of ERM Practices. Information, 11(6), 297. https://doi.org/10.3390/info11060297

Kumar, R. (2017). Targeted SME Financing and Employment Effects: What Do We Know and What Can We Do Differently? World Bank. https://doi.org/10.1596/27477

Liu, H., Wei, S., Ke, W., Wei, K. K., \& Hua, Z. (2016). The configuration between supply chain integration and information technology competency: A resource orchestration perspective. Journal of Operations Management, 44, 13-29. https://doi.org/10.1016/j.jom.2016.03.009

Lusardi, A., \& Mitchell, O. S. (2014). The economic importance of financial literacy: Theory and evidence. Journal of Economic Literature, 52(1), 5-44. https://doi.org/10.1257/jel.52.1.5

Lusardi, A., \& Tufano, P. (2015). Debt literacy, financial experiences, and overindebtedness. Journal of Pension Economics \& Finance, 14(4), 332-368. https://doi.org/10.1017/S1474747215000232

Magnier-Watanabe, R., \& Senoo, D. (2008). Organizational characteristics as prescriptive factors of knowledge management initiatives. Journal of Knowledge Management, 12(1) 21-36. https://doi.org/10.1108/13673270810852368

Makhloufi, L., Yaacob, N. A., \& Yamin, F. M. (2018). Investigation on the Relationship between IT and Core Competency on the Sustainable Competitive Advantage of Malaysian SMEs. Journal of International Business and Management, 1(2), 1-15.

Mardijuwono, A. W., \& Subianto, C. (2018). Independence, professionalism, professional skepticism: The relation toward the resulted audit quality. Asian Journal of Accounting Research, 3(1), 61-71. https://doi.org/10.1108/AJAR-06-2018-0009

Margaretha, F., \& Pambudhi, R. A. (2015). Tingkat literasi keuangan pada mahasiswa S-1 Fakultas Ekonomi. Jurnal Manajemen Dan Kewirausahaan, 17(1), 76-85. https://doi.org/10.9744/jmk.17.1.76-85

Mesfin, D., Woldie, M., Adamu, A., \& Bekele, F. (2020). Perceived organizational culture and its relationship with job satisfaction in primary hospitals of Jimma zone and Jimma town administration, correlational study. BMC Health Services Research, 20, 1-9. https://doi.org/10.1186/s12913-020-05319-X

Miswanto, M., Arifin, R., \& Murniyati, D. (2020). Does work commitment mediates the effect of Islamic work ethic on performance and turnover intention? JEMA: Jurnal 
The mediation role of financial literation in ensuring MSMEs sustainability: An organizational characteristics perspective by Arik Prasetya, Kusdi Rahardjo, Mukhammad Kholid Mawardi,

Raden Rustam Hidayat, Yudha Prakasa

Ilmiah Bidang Akuntansi Dan Manajemen, 17(2), 169-187. https://doi.org/http://dx.doi.org/10.31106/jema.v17i2.5533

Oseifuah, E., Gyekye, A., \& Formadi, P. (2018). Financial literacy among undergraduate students: Empirical evidence from Ghana. Academy of Accounting and Financial Studies Journal, 22(6), 1-17.

Rai, K., Dua, S., \& Yadav, M. (2019). Association of financial attitude, financial behaviour and financial knowledge towards financial literacy: A structural equation modeling approach. FIIB Business Review, 8(1), 51-60.

Robbins, S. P. (2003). Organizational Behavior. Upper Saddle River : Prentice Hall.

Salimath, M. S., \& Jones, R. (2011). Population ecology theory: implications for sustainability. Management Decision, 49(6), 874-910. https://doi.org/10.1108/00251741111143595

Santoro, M. D., \& Gopalakrishnan, S. (2000). The institutionalization of knowledge transfer activities within industry-university collaborative ventures. Journal of Engineering and Technology Management, 17(3-4), 299-319. https://doi.org/10.1016/S09234748(00)00027-8

Schwab, L., Gold, S., \& Reiner, G. (2019). Exploring financial sustainability of SMEs during periods of production growth: A simulation study. International Journal of Production Economics, 212, 8-18. https://doi.org/10.1016/j.ijpe.2018.12.023

Siegel, R., Antony, J., Garza-Reyes, J. A., Cherrafi, A., \& Lameijer, B. (2019). Integrated green lean approach and sustainability for SMEs: From literature review to a conceptual framework. Journal of Cleaner Production, 240, 118205. https://doi.org/10.1016/j.jclepro.2019.118205

Stadler, C., Helfat, C. E., \& Verona, G. (2013). The impact of dynamic capabilities on resource access and development. Organization Science, 24(6), 1782-1804. https://doi.org/10.1287/orsc.1120.0810

Swiecka, B., Yeşildağ, E., Özen, E., \& Grima, S. (2020). Financial literacy: The case of Poland. Sustainability, 12(2), 700. https://doi.org/10.3390/su12020700

Urinov, B. N. (2020). Theoretical aspects of organizational behavior and corporate culture. Economics and Innovative Technologies, 2020(2), 15.

Velazquez, L. E., Esquer, J., Munguía, N. E., \& Moure-Eraso, R. (2011). Sustainable learning organizations. The Learning Organization, 18(1), 36-44. https://doi.org/10.1108/09696471111095984 
Widayanti, R., Damayanti, R., \& Marwanti, F. (2017). Pengaruh Financial Literacy Terhadap Keberlangsungan Usaha (Business Sustainability) Pada UMKM Desa Jatisari. Jurnal Ilmiah Manajemen \& Bisnis, 18(2), 153. https://doi.org/10.30596/jimb.v18i2.1399

Wignaraja, G. and Y. N. (2015). SMEs Internationalization and Finance in Asia. https://www.imf.org/external/np/seminars/eng/2015/jica2015/pdf/1-B1.pdf

Ye, J., \& Kulathunga, K. (2019). How Does Financial Literacy Promote Sustainability in SMEs? A Developing Country Perspective. Sustainability, 11(10), 2990. https://doi.org/10.3390/su11102990

Yusoff, Y. M., Omar, M. K., \& Zaman, M. D. K. (2019). Does organizational learning capability allow improving business sustainability? A quantitative analysis in the manufacturing SME context. IOP Conference Series: Materials Science and Engineering, 469(1), 12015.

Zaridis, A. D., \& Mousiolis, D. T. (2014). Entrepreneurship and SME's organizational structure. Elements of a successful business. Procedia-Social and Behavioral Sciences, $148,463-467$. 